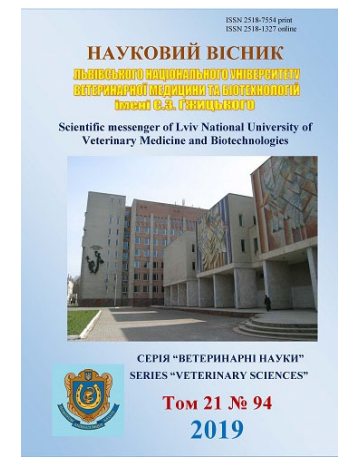

\author{
Науковий вісник Дьвівського національного університету \\ ветеринарної медицини та біотехнологій імені С.З. Гжицького. \\ Серія: Ветеринарні науки \\ Scientific Messenger of Lviv National University \\ of Veterinary Medicine and Biotechnologies. \\ Series: Veterinary sciences
}

\title{
Dynamics of total protein content in blood of sows depending on peculiarities of nervous system activity
}

\author{
R. Postoi, V. Karpovskyi, O. Danchuk, D. Kryvoruchko \\ National University of Life and Environmental Sciences of Ukraine, Kyiv, Ukraine
}

Article info

Received 28.03.2019

Received in revised form 29.04.2019

Accepted 30.04.2019

National University of Life and Environmental Sciences of Ukraine Heroyiv Oborony Str., 15, Kyiv, 03041, Ukraine.

Tel.: +38-050-386-56-51

E-mail: ruslana-postoy@meta.ua

Postoi, R., Karpovskyi, V., Danchuk, O., \& Kryvoruchko, D. (2019). Dynamics of total protein content in blood of sows depending on peculiarities of nervous system activity. Scientific Messenger of Lviv National University of Veterinary Medicine and Biotechnologies. Series: Veterinary sciences, 21(94), 51-56. doi: 10.32718/nvlvet9409

The article presents the results of studies on the dynamics of total protein content in blood serum of sows depending on the cortical and vegetative mechanisms of regulation under exposure to technological stimulus. Experiments were carried out on 3 years old pigs of large white breed. Types of higher nervous activity in pigs were determined using method of conditioned food reflexes. According to the studying of conditioned reflex activity 4 experimental groups were formed, 5 animals in each. The $1^{\text {-st }}$ group consisted of sows with strong balanced mobile, the $2^{-n d}$-strong balanced inert, the $3^{\text {-rd }}-$ strong unbalanced, and the $4^{\text {th }}$ - weak types of higher nervous activity. Then in experimental animals we studied the tone of the autonomic nervous system using trygeminovagal test, by the results of which we formed 3 experimental groups (normotonics, sympathicotonics, vagotonics), 5 animals in each. Before exposure to technological stimulus and in 1, 3, 7, 14 and 28 days after its impact, blood samples were taken for biochemical studies in all experimental animals. Before exposure to technological stimulus content of total protein in swine blood serum between animals with strong types of higher nervous activity did not differ significantly. Animals with weak type of higher nervous activity had lower level of this metabolite than animals with strong balanced mobile type. After exposure to technological stimulus the total protein level in swine blood serum significantly decreased. In sows with strong balanced mobile type, the content of total protein starting from the $7^{\text {th }}$ day after exposure to technological stimulus returned to values that were before stress factor impact. At the same time, in sows with weak type of higher nervous activity, the level of total protein in blood returned to the reference values only in 28 days after exposure to technological stimulus. The basal level of total protein in blood serum in pigs with different tone of autonomic nervous system didn't differ significantly. In sows normotonics was found a significantly higher content of total protein in blood serum than in sows vagotonics and sympathicotonics during first week after exposure to stress factor.

Key words: pigs, types of higher nervous activity, autonomic nervous system, blood, total protein, stress.

\section{Динаміка вмісту загального білка в крові свиноматок залежно від особливостей діяльності нервової системи}

\author{
Р.В. Постой, В.І. Карповський, О.В. Данчук, Д.І. Криворучко
}

Національний університет біоресурсів і природокористування України, м. Київ, Украӥна

\footnotetext{
У статті наведено результати досліджень динаміки вмісту загального білка в сироватці крові свиноматок залежно від кортико-вегетативних механізмів регуляиії за умови дії технологічного подразника. Досліди проводили на свиноматках великої білої породи 3-річного віку. Типи вищуї нервової діяльності у свиней визначали за допомогою методики умовних харчових рефлексів. За результатами дослідження умовно-рефлекторної діяльності сформували 4 дослідні групи, по 5 тварин у кожній. До периої групи входили тварини сильного врівноваженого рухливого, до другої-сильного врівноваженого інертного, до третьої-сильного неврі-
} 
вноваженого, до четвертої - слабкого типів вищяої нервової діяльності. Потім у тварин всіх дослідних груп досліджували тонус автономної нервової системи тригеміновагальним тестом, за результатами якого сформували 3 дослідні групи (нормотоніки, симпатикотоніки, ваготоніки), по 5 тварин у кожній. До впливу технологічного подразника та через 1, 3, 7, 14 і 28 діб після його впливу в усіх дослідних тварин відбирали зразки крові для біохімічних досліджень. До впливу технологічного подразника вміст загального білка в сироватці крові у свиноматок сильних типів вищої нервової діяльності істотно не відрізнявся. У тварин слабкого типу вищсої нервової діяльності рівень иьього метаболіту був вірогідно мениим, ніж у тварин сильного врівноваженого рухливого типу. Після впливу технологічного подразника рівень загального білка в сироватиі крові свиней вірогідно змениувався. У свиноматок сильного врівноваженого рухливого типу вміст загального білка, починаючи з 7-ої доби після дії технологічного подразника, повертався до значень, щчо були до впливу стрес-фактора. Водночас у свиноматок слабкого типу вищої нервової діяльності рівень загального білка в крові повертався до референтного значення лише через 28 діб після впливу технологічного подразника. Базальний рівень загального білка в сироватиі крові у свиней з різним тонусом вегетативної нервової системи суттєво не відрізнявся. У свиноматок нормотоніків протягом першого тижня після впливу стресового фактора встановлено вірогідно вищий вміст загального білка в сироватці крові, ніж у свиноматок ваго- $і$ симпатикотоніків.

Ключові слова: свині, типи вищої нервової діяльності, автономна нервова система, кров, загальний білок, стрес.

\section{Вступ}

Сучасні технології вирощування свиней забезпечують найбільш ефективне використання їхнього генетичного потенціалу. Однак за таких умов свині часто піддаються впливу різноманітних стресових факторів, які призводять до зниження їхньої продуктивності, сприяють виникненню захворювань і завдають значних економічних збитків (Lee et al., 2016). Серед домашніх тварин свині є одним 3 найбільш чутливих до впливу стресових факторів видів. Тому вивчення адаптаційних можливостей організму свиней та їхньої стресостійкості $є$ актуальним.

Діяльність нервової системи насамперед спрямована на підтримку гомеостазу в організмі тварини у відповідь на вплив внутрішніх та зовнішніх подразників. Автономна нервова система (АНС) регулює всі метаболічні процеси в живому організмі, підтримуе сталість внутрішнього середовища, координує функції внутрішніх органів, залоз і серцево-судинної системи. Крім того, вона бере участь в адаптації до мінливих умов навколишнього середовища (Karpovskyi et al., 2015). Координацію активності АНС забезпечують гіпоталамус і кора головного мозку. Значну увагу дослідників привертає вивчення впливу типу автономної регуляції серцевого ритму на будову та функції органів, а також продуктивність тварин (Kononenko, 2004; Demus, 2010; Tybinka, 2015; Kushch 2016; Bobrytska et al., 2018; Zhurenko, 2018). Розкрито особливості антиоксидантної системи у свиноматок з різним тонусом AHC (Skrypkina et al., 2016). Варто зауважити, що даних щодо обміну білка в організмі свиноматок залежно від типу автономної регуляції за умови дії технологічного подразника не знайдено.

Попередніми дослідженнями встановлено наявність вірогідного тісного взаємозв'язку між основними властивостями вищої нервової діяльності (ВНД) та особливостями вегетативної регуляції фізіологічних функцій організму свиней (Karpovskyi et al., 2015). У літературі наведено дані щодо впливу типу ВНД на показники обміну білків у 5-6-ти місячних свиней, однак не висвітлено питання щодо їхнього вмісту в крові свиноматок внаслідок дії стресу.

Мета роботи - дослідити зміни вмісту загального білка в сироватці крові свиноматок залежно від типу ВНД та автономної регуляції серцевого ритму за умови дії технологічного подразника.

\section{Матеріал і методи досліджень}

Досліди проводили на базі виробничої свиноферми ТОВ СП “Ідна”, с. Острожець Млинівського району Рівненської області на свинях великої білої породи 3-річного віку. Умови утримання, використання, раціон та кратність годівлі для всіх тварин були однаковими. На першому етапі досліджень визначали типи ВНД за експрес-методикою, розробленою кафедрою фізіології, патофізіології та імунології тварин НУБіП України, суть якої полягає в оцінці рухової реакції тварини до місця підкріплення кормом, швидкості вироблення та переробки умовного рухово-харчового рефлексу, ступеня орієнтувальної реакції та зовнішнього гальмування. На основі проведених досліджень умовно-рефлекторної діяльності сформовано 4 дослідні групи тварин по 5 найтиповіших представників визначених типів ВНД в кожній: I група - сильний врівноважений рухливий тип, II група - сильний врівноважений інертний тип, III група - сильний неврівноважений тип, IV група - слабкий тип. Другий етап експериментів включав дослідження тонусу АНC у піддослідних свиней за допомогою тригеміновагального тесту. У кожної тварини вимірювали частоту серцевих скорочень шляхом аускультації серця зліва, у ділянці 2-4-го міжреберного проміжку у нижній третині грудної клітки за допомогою фонендоскопу. Потім експериментатор натискав одночасно великим i вказівним пальцями на обидва очні яблука досліджуваної тварини з експозицією 10 секунд. Після натискання частоту серцевих скорочень вимірювали повторно. Визначали різницю частоти серцевих скорочень до та після натискання на очні яблука. За результатами тригеміновагального тесту встановлювали тип автономної регуляції серцево-судинної системи та сформували 3 дослідні групи (нормотоніків, симпатикотоніків, ваготоніків), по 5 тварин у кожній.

Після дослідження умовно-рефлекторної діяльності та вегетативного гомеостазу провели перегрупування та переміщення до іншого приміщення всіх тварин (технологічний подразник). До впливу технологічного подразника та через 1, 3, 7, 14 і 28 діб після його дії в усіх тварин відбирали зразки крові для біохімічних досліджень 3 яремної вени із дотриманням правил асептики та антисептики. Вміст загального білка визначали у сироватці крові за біуретовим методом (Vlizlo, 2012). Обробку одержаних результатів 
досліджень проводили за допомогою персонального комп'ютера, використовуючи програму Microsoft Office Exel 2007. Розраховували середнє арифметичне значення (М) і помилку середнього арифметичного значення (m) (Vlizlo, 2012). Вірогідність відмінностей оцінювали за коефіцієнтом вірогідності таблиці Стьюдента (Р) та вважали різницю між показниками вірогідною за $\mathrm{P} \leq 0,05$.

\section{Результати та їх обговорення}

Кров як різновид сполучної тканини характеризується відносною сталістю складу, а динамічні зміни (у фізіологічних межах) як біохімічного, так і морфологічного характеру відображають фізіологічні процеси, що відбуваються в організмі (Ostapyuk \& Gutyj, 2018). Внаслідок дії стрес-фактора в організмі відбуваються метаболічні зрушення, що спрямовані на запуск механізмів адаптації до змінених умов довкілля. Провідна роль в адаптації організму до нових умов існування належить АНС, а саме - симпатоадреналовій системі. Водночас, ступінь прояву адаптивних процесів в організмі тварин залежить від походження, сили та тривалості дії стрес-фактора. У стані відносного спокою свиноматки із різним тонусом АНС не відрізнялись між собою за вмістом загального білка у сироватці крові (табл. 1).
Дія технологічного подразника вірогідно впливає на вміст загального білка в сироватці крові свиноматок, причому зменшення його вмісту певним чином лімітовано тонусом АНС. Зокрема у свиноматок із збалансованими впливами на роботу серця симпатичного та парасимпатичного відділів АНС встановлено вірогідно вищий рівень загального білка у сироватці крові з 1-ої до 7-ої доби після дії стресового фактора, ніж у свиноматок із ваго- або симпатикотонією. Через добу після дії технологічного подразника у свиноматок ваго- та симпатикотоніків вміст загального білка у сироватці крові був меншим відповідно на 9,4 та $12,7 \%$ ( $<<0,05)$, ніж у свиноматок нормотоніків. Аналогічні дані отримано на 3-тю та 7-му добу після дії технологічного подразника - тварини нормотоніки переважали за вмістом загального білка в сироватці крові тварин ваго- та симпатикотоніків на 8,1-14,4\% $(\mathrm{P}<0,05)$, тим часом як на 14 -ту та 28 -му добу після дії технологічного подразника свиноматки 3 різним типом вегетативного гомеостазу не відрізнялися між собою за вмістом загального білка в сироватці крові. Варто зазначити, що у свиноматок нормотоніків спостерігали відсутність вірогідних відмінностей вмісту загального білка порівняно з базальним рівнем починаючи з 7-ої доби після впливу технологічного подразника, тоді як у ваго- та симпатикотоніків - лише починаючи з 14-ої доби.

\section{Таблиця 1}

Динаміка вмісту загального білка в сироватці крові свиноматок залежно від особливостей нервової системи в умовах технологічного стресу, г/л, $\mathrm{M} \pm \mathrm{m}, \mathrm{n}=5$

\begin{tabular}{|c|c|c|c|c|c|c|}
\hline \multirow{2}{*}{ Група тварин } & \multicolumn{6}{|c|}{ Період досліджень } \\
\hline & До дії подразника & Через 1 добу & Через 3 доби & Через 7 діб & Через 14 діб & Через 28 діб \\
\hline \multicolumn{7}{|c|}{ За типом вищої нервової діяльності } \\
\hline $\begin{array}{l}\text { Сильний врівноважений } \\
\text { рухливий }\end{array}$ & $75,6 \pm 1,2$ & $70,1 \pm 1,8$ & $68,5 \pm 1,0$ & $70,6 \pm 2,5$ & $72,5 \pm 0,9$ & $74,96 \pm 2,1$ \\
\hline $\begin{array}{l}\text { Сильний врівноважений } \\
\text { інертний }\end{array}$ & $74,2 \pm 2,8$ & $65,9 \pm 2,2$ & $63,9 \pm 2,0^{*}$ & $63,0 \pm 2,8$ & $67,5 \pm 1,4$ & $73,1 \pm 1,3$ \\
\hline Сильний неврівноважений & $74,2 \pm 1,4$ & $62,08 \pm 2,5^{*}$ & $63,1 \pm 2,1^{* *}$ & $65,7 \pm 2,1$ & $71,2 \pm 3,4$ & $73,8 \pm 3,5$ \\
\hline Слабкий & $71,0 \pm 1,2 *$ & $59,00 \pm 1,98 * *$ & $58,0 \pm 2,1 * * *$ & $57,2 \pm 2,3^{* *}$ & $62,4 \pm 2,3 * *$ & $67,9 \pm 1,9 *$ \\
\hline \multicolumn{7}{|c|}{ За тонусом автономної нервової системи } \\
\hline Нормотс & $75,2 \pm 1,6$ & $70,3 \pm 1,8$ & $67,9 \pm 1,4$ & $70,0 \pm 2,1$ & $71,3 \pm 2,6$ & $75,7 \pm 2,9$ \\
\hline Ваготоніки & $74,9 \pm 2,7$ & $63,7 \pm 2,5^{\circ}$ & $62,4 \pm 1,8^{\circ}$ & $64,2 \pm 1,2^{\circ}$ & $69,1 \pm 1,5$ & $74,6 \pm 1,3$ \\
\hline Симпатотоніки & $72,5 \pm 1,4$ & $61,4 \pm 2,6^{\circ}$ & $60,8 \pm 2,8^{\circ}$ & $59,9 \pm 3,4^{\circ}$ & $65,5 \pm 4,5$ & $71,3 \pm 2,9$ \\
\hline
\end{tabular}

Примітки. * - ${ }^{*}<0,05 ; * *-\mathrm{P}<0,01 ; * * *-\mathrm{P}<0,001-$ відносно тварин сильного врівноваженого рухливого типу ВНД; $\circ-\mathrm{P}<0,05-$ відносно тварин нормо тоніків

Внаслідок впливу технологічного подразника у свиноматок, незважаючи на належність до того чи іншого типу ВНД, встановлено зниження вмісту загального білка у крові протягом перших 14-ти діб, тоді як на 28-му добу досліджуваний показник суттєво не відрізнявся від вихідних значень. У свиноматок сильного врівноваженого рухливого типу ВНД вірогідно нижчий вміст загального білка у сироватці крові порівняно $з$ початковими значеннями спостерігали лише через добу (на 7,2\%; Р < 0,05) та 3 доби (на 9,4\%; $\mathrm{P}<0,05)$ після дії технологічного подразника. Надалі, через 7 та 14 діб у тварин цього типу ВНД відмічено лише тенденцію до нижчого вмісту загального білка у сироватці крові порівняно з початковими значеннями.

У свиноматок сильного врівноваженого інертного типу ВНД встановлено менший вміст загального білка у сироватці крові на 9,0-15,0\% (P < 0,05-0,01) 31 ої до 14-ої доби після дії технологічного подразника порівняно з початковими значеннями.

У свиноматок сильного неврівноваженого типу ВНД впродовж тижня доби після дії технологічного подразника спостерігали менший вміст загального білка у сироватці крові відповідно на 11,4-16,3\% ( $<<0,01)$. Однак, починаючи 3 14-ої доби, рівень загального білка у сироватці крові цих свиноматок 
сильного вже вірогідно не відрізнявся від вихідних значень.

Свиноматки слабкого типу ВНД характеризувалися значним та тривалим зниженням вмісту загального білка в крові під впливом технологічного подразнення. У свиноматок цього типу ВНД через добу після дії технологічного подразника вміст загального білка в сироватці крові був меншим на 17,0\% (P <0,001), через 3 доби - на 18,4\% (P < 0,001), через 7 діб - на $19,5 \%(\mathrm{P}<0,001)$ та через 14 діб - на $12,2 \%(\mathrm{P}<0,01)$ порівняно з вихідними значеннями.

До впливу технологічного подразника свиноматки сильних (сильного врівноваженого рухливого, сильного врівноваженого інертного і сильного неврівноваженого) типів ВНД істотно не відрізнялися між собою за вмістом загального білка в сироватці крові, тоді як свиноматки слабкого типу мали достовірно менші значення цього показника на 6,0\% (P < 0,05), ніж свиноматки сильного врівноваженого рухливого типу. Отримані дані щодо вмісту загального білка в крові свиноматок різних типів ВНД у стані відносного спокою узгоджуються з результатами дослідів проведених на свинях 5-6-ти місячного віку (Trokoz et al., 2012).

Під час дослідження вмісту загального білка у крові свиней за умови впливу технологічного подразника встановлено відмінності, які пов'язані з типологічними особливостями діяльності нервової системи. Встановлено, що впродовж усього дослідного періоду свиноматки сильного врівноваженого рухливого типу ВНД характеризувалися вірогідно вищим рівнем загального білка у сироватці крові на 6,0-18,2\% (P < 0,05$0,01)$ порівняно зі свиноматками слабкого типу. Свиноматки сильного врівноваженого інертного типу ВНД мали більший вміст загального білка у сироватці крові ніж свиноматками слабкого типу після 1-ої та 3ої доби дії технологічного подразника, тимчасом як свиноматки сильного неврівноваженого типу - після 7-ої та 14-ої доби. Варто зазначити, що на 14-ту добу після дії технологічного подразника у свиноматок сильного врівноваженого інертного типу ВНД відмічали менший вміст загального білка у сироватці крові (на 6,9\% за Р < 0,05), ніж у свиноматок сильного врівноваженого рухливого типу. Встановлено, що через 1 та 3 доби після дії технологічного подразника вміст загального білка у сироватці крові свиноматок сильного неврівноваженого типу ВНД був нижчим відповідно на $11,5 \%(\mathrm{P}<0,01)$ та 7,8\% $(\mathrm{P}<0,05)$, ніж у свиноматок сильного врівноваженого рухливого типу.

Для оцінки стресового стану в організмі використовують різноманітні тести (Einarsson et al., 2008). До маркерів стресу відносять кортизол - гормон кори наднирників, що може відображати силу реакції організму на дію стресового фактора. Дослідженя Danchuk et al. (2017) показали, що у тварин слабкого типу вміст кортизолу після дії технологічного стресфактора протягом місяця був вірогідно вищим, ніж у тварин сильних типів. Крім того, із збільшенням сили та врівноваженості процесів збудження та гальмування у корі головного мозку знижувався вміст кортизо- лу у крові тварин. На думку Salak-Johnson (2017), перегрупування свиноматок викликає стан хронічного стресу не в усіх тварин, а лише у окремих особин. У наших дослідженнях вплив технологічного подразника зумовив суттєве та довготривале зниження рівня загального білка в крові свиноматок слабкого типу ВНД, що може бути пов'язано з виникненням хронічного стресового стану в тварин цього типу.

Свині слабкого типу ВНД характеризуються низькою стресостійкістю та низьким адаптаційним потенціалом, що, безумовно, пов'язано із слабкістю, неврівноваженістю та низькою рухливістю процесів збудження і гальмування у корі великого мозку. Внаслідок дії технологічного подразника у свиноматок сильного врівноваженого рухливого типу ВНД відмічали незначні зміни вмісту білка в сироватці крові порівняно з свиноматками інших типів, починаючи 3 7-ої доби, вірогідних відмінностей відносно початкових значень не встановлено. Така реакція організму свиноматок сильного врівноваженого рухливого типу ВНД свідчить про високу адаптогенність, тобто здатність швидко пристосовуватись до змін умов навколишнього середовища та відновлювати гомеостаз. На нашу думку, це пояснюється високою стресостійкістю тварин цього типу та оптимальним співвідношенням сили, врівноваженості та рухливості нервових процесів, що забезпечує швидку адаптацію організму. У свиноматок сильного врівноваженого інертного типу ВНД спостерігали поступове відновлення вмісту загального білка - лише на 28-му добу, що може бути пов'язано з низькою рухливістю нервових процесів та деякою повільністю в утворенні нових умовних рефлексів. Свиноматки сильного неврівноваженого типу ВНД, хоч і характеризувалися значним зниженням вмісту загального білка в крові, однак досить швидко почали відновлювати його вихідний рівень - починаючи 3 14-ої доби, що, очевидно, пов'язано з високою силою та рухливістю нервових процесів. Таким чином, отримані нами дані узгоджуються із наявними даними щодо стресостійкості тварин з різними параметрами кортико-вегетативної регуляції фізіологічних функцій організму.

\section{Висновки}

У стані відносного спокою у свиноматок сильного врівноваженого рухливого типу вищої нервової діяльності встановлено вищий вміст загального білка у сироватці крові порівняно з свиноматками слабкого типу, тимчасом як між свиноматками з різним вихідним вегетативним статусом вірогідних відмінностей не виявлено. Внаслідок дії технологічного подразника у свиноматок спостерігали зменшення вмісту загального білка у сироватці крові, однак ступінь прояву цих змін залежав від типологічних характеристик їхньої нервової системи. За умови впливу технологічного подразника у свиноматок із збалансованим симпатичним і парасимпатичним відділом нервової системи спостерігали вищий вміст загального білка у 
сироватці крові, ніж у свиноматок ваго- та симпатикотоніків.

Перспективи подальших досліджень. Попередніми дослідженнями встановлено роль типу вищої нервової діяльності у регуляції обміну білків в організмі тварин. У зв'язку $з$ відсутністю подібних даних щодо впливу типу вегетативної регуляції серцево-судинної системи вважаємо за доцільне дослідження інших показників обміну білка в організмі свиноматок залежно від кортико-вегетативної регуляції.

\section{References}

Bobrytska, O., Ugai, K., \& Karpovsky, V. (2018). Biorezonansnyi metod korektsii funktsionalnoho stanu avtonomnoi nervovoi systemy $u$ sobak [The bioresonance method of correcting the functional state of the autonomous nervous system in dogs]. Naukovi dopovidi NUBiP Ukrainy, 5(75). doi: 10.31548/dopovidi2018.05.025 (in Ukrainian).

Danchuk, O.V., Karpovskyi, V.I., Trokoz, V.O., \& Postoi, R.V. (2017). Regulation mechanisms of cortisol level in pigs' blood serum under stress. Fiziologichnyi Zhurnal, 63(6), 60-65. doi: 10.15407/fz63.06.060 (in Ukrainian).

Demus, N.V. (2010). Histolohichna kharakterystyka miokardu telychok zalezhno vid typu avtonomnoi rehuliatsii sertsevoho rytmu [Histological characteristics of the myocardium of the calves depending on the type of autonomic regulation of the heart rate]. Naukovyi visnyk Lvivskoho natsionalnoho universytetu veterynarnoi medytsyny ta biotekhnolohii im. S.Z. Gzhytskoho, 12 (3-2 (45)), 63-69. Retrieved from https://cyberleninka.ru/article/n/gistologichnaharakteristika-miokardu-telichok-zalezhno-vid-tipuavtonomnoyi-regulyatsiyi-sertsevogo-ritmu Ukrainian).

Einarsson, S., Brandt, Y., Lundeheim, N., \& Madej, A. (2008). Stress and its influence on reproduction in pigs: a review. Acta Veterinaria Scandinavica, 50(48), 1-8. doi: 10.1186/1751-0147-50-48.

Karpovskyi, P.V., Karpovskyi, V.V., Trokoz, A.V., Landsman, A.O., Skrypkina, V.M., Postoi, R.V., ... \& Karpovskyi, V.I. (2015). Kortyko-vehetatyvni vzaiemyny $\mathrm{V}$ rehuliatsii fiziolohichnykh funktsii orhanizmu svynei [Cortico-vegetative relationships in the regulation of the physiological functions of the pig's body]. Biolohiia tvaryn, 17(2), 65-73. Retrieved from http://aminbiol.com.ua/20152pdf/7.pdf (in Ukrainian).

Kononenko, V.S. (2004). Typy avtonomnoi rehuliatsii funktsii i produktyvnist silskohospodarskykh tvaryn [Types of autonomous regulation of functions and productivity of farm animals]. Naukovyi visnyk Lvivskoho natsionalnoho universytetu veterynarnoi medytsyny ta biotekhnolohii im. S.Z. Gzhytskoho, 6, 1(2), 174-179 (in Ukrainian).
Kushch, M.M. (2016). The peculiarities of microscopic structure of geese enterosympathetic nervous system. Bìologia Tvaryn, 18(2), 59-67. doi: 10.15407/animbiol18.02.059 (in Ukrainian).

Lee, I.K., Kye, Y.C., Kim, G., Kim, H.W., Gu, M.J., Umboh, J., ... \& Yun, C.-H. (2016). Stress, nutrition, and intestinal immune responses in pigs - A review. Asian-Australasian Journal of Animal Sciences, 29(8), 1075-1082. doi: 10.5713/ajas.16.0118.

Naumenko, V.V. (2004). Osoblyvosti umovnoreflektornoi diialnosti, typy nervovoi systemy ta yikh zviazok z deiakymy funktsiiamy u svynei [Features of conditioned reflex activity, types of the nervous system and their connection with some functions in pigs]. Naukovyi visnyk natsionalnoho ahrarnoho universytetu, 78, 13-34 (in Ukrainian).

Ostapyuk, A.Y., \& Gutyj, B.V. (2018). Influence of cadmium loading on morphological parameters of blood of the Laying Hens. Scientific Messenger of Lviv National University of Veterinary Medicine and Biotechnologies, 20(88), 48-52. doi: 10.32718/ nvlvet8808 (in Ukrainian).

Salak-Johnson, J.L. (2017). Social status and housing factors affect reproductive performance of pregnant sows in groups. Molecular Reproduction and Development, 84. doi: 10.1002/mrd.22846.

Skrypkina, V.M., Karpovsky, V.I., Danchuk, O.V., Postoi, R.V., Krivoruchko, D.I., \& Ukrainec, M.A. (2016). Aktyvnist ta zbalansovanist fermentatyvnoi systemy antyoksydantnoho zakhystu $\mathrm{V}$ orhanizmi svynei iz riznym tonusom avtonomnoi nervovoi systemy [The activity and the balance of the enzymatic system of antioxidant defense in pigs with different tones of the autonomic nervous system]. Naukovyi visnyk Lvivskoho natsionalnoho universytetu veterynarnoi medytsyny ta biotekhnolohii im. S.Z. Gzhytskoho, 18(1(2)), 145-149. Retrieved from http://nbuv.gov.ua/UJRN/nvlnu_2016_18_1(2)_28 (in Ukrainian).

Trokoz, A.V., Karpovskiy, V.I., Trokoz, V.O., Kryvoruchko, D.I., \& Vasyliv, A.P. (2012). Vmist zahalnoho bilka ta yoho fraktsii u syrovattsi krovi svynei riznykh typiv vyshchoi nervovoi diialnosti [The content of the general protein and its fractions in serum of blood of pigs of the highest nervous activity various types]. Biolohiia tvaryn, 14 (1-2), 202-206. Retrieved from http://nbuv.gov.ua/UJRN/bitv_2012_14_1-2_32 (in Ukrainian).

Tybinka, A.M. (2015). Vplyv riznoi typolohii avtonomnoho tonusu na pokaznyky slyzovoi obolonky kyshechnyku kurei [Influence of different typologies of autonomous tone on indicators of intestinal mucosa of hens]. Naukovyi visnyk Lvivskoho natsionalnoho universytetu veterynarnoi medytsyny ta biotekhnolohii im. S.Z. Gzhytskoho, 17(3), 108-112. Retrieved from https://nvlvet.com.ua/index.php/journal/article/view/5 28 (in Ukrainian). 
Vlizlo, V.V. (2012). Laboratorni metody doslidzhen u biolohiyi, tvarynnytstvi ta veterynarniy medytsyni [Laboratory methods of investigation in biology, stock-breeding and veterinary]. Spolom, Lviv (in Ukrainian).

Zhurenko, O., Karpovskiy, V., Danchuk, O., \& Kravchenko-Dovga, Y. (2018). The content of calcium and phosphorus in the blood of cows with a different tonus of the autonomic nervous system. Scientific Messenger of Lviv National University of Veterinary Medicine and Biotechnologies, 20(92), 812. doi: $10.32718 /$ nvlvet8808 (in Ukrainian). 